\title{
Identifikasi Kerusakan PC (Personal Computer) dengan Metode Teorema Bayes Pada Laboratorium Komputer STMIK Triguna Dharma
}

\author{
Rendy Syahputra \\ Program Studi Sistem Informasi, STMIK Triguna Dharma
}

\begin{abstract}
ABSTRAK
Kerusakan Personal computer yang sering terjadi di STMIK Triguna Dharma Medan akan menjadi probabilitas untuk diproses menggunakan metode Teorema Bayes, dimana data yang didapat selama 5 tahun terakhir dapat menjadi referensi. Metode ini cocok digunakan untuk sistem pakar yang dalam mengidentifikasi sesuatu yang belum pasti dengan melakukan perhitungan secara akurat untuk menentukan nilai keyakinannya.Hasil dari Pengujian terhadap metode ini adalah computer mati total 80 $\%$ karena pawer supply, computer tiba-tiba mati $70 \%$ karena kerusakan kipas prosesor. Hasil persentase kerusakan sudah cukup akurat karena berkisar $80 \%$ untuk kerusakan pawer supply dan $7 \%$ untuk kerusakan kipas prosesor, dari hasil tersebut dapat direkomendasikan untuk membantu teknisi komputer dalam mengidentifikasi kerusakan computer untuk akurasi yang baik
\end{abstract}

Kata kunci : System Pakar, Kerusakan PC, Teorema Bayes, Identifikasi Kerusakan, Solusi Perbaikan,

\begin{abstract}
Personal computer damage that often occurs in STMIK Triguna Dharma Medan will be a probability to be processed using the Bayes Theorem method, where data obtained over the past 5 years can be a reference. This method is suitable for expert systems that identify something that is uncertain by calculating accurately to determine the value of the belief. The results of this method testing is that the computer dies $80 \%$ of the total due to supply control, the computer suddenly dies $70 \%$ due to fan damage processor. The result of percentage damage is quite accurate because it ranges from $80 \%$ for damage to pawer supply and $7 \%$ for damage to the processor fan, from these results it can be recommended to help computer technicians in identifying computer damage for good accuracy
\end{abstract}

Keywords : Expert System, PC Damage, Bayes Theorem, Damage Identification, Repair Solution

\section{PENDAHULUAN}

Pada saat ini, perkembangan dan kemajuan zaman membuat PC (Personal Computer) menjadi perangkat yang sangat penting dalam kehidupan sebagai alat pengolah data dan informasi yang paling utama, kini fungsi PC digunakan dalam berbagai bidang seperti: bisnis, militer, pendidikan, psikologi, permainan, kesehatan dan lain-lain. Komputer atau disebut PC terdiri dari dua bagian penting yaitu Perangkat keras (Hardware) dan Perangkat Lunak (Software), bagian pertama adalah Hardware komputer berupa alat yang dapat di lihat dan di pegang seperti: monitor, keyboard, mouse, printer, CPU (Central Processing Unit) dan semua perangkat didalamnya [1]. Kecerdasan buatan atau Artificial Intelligence merupakan salah satu bagian ilmu komputer yang membuat agar mesin (komputer) dapat melakukan pekerjaan seperti dan sebaik yang dilakukan oleh manusia [2]. 
Sistem pakar adalah sistem berbasis komputer yang menggunakan pengetahuan, fakta, dan teknik penalaran dalam memecahkan masalah yang hanya dapat dipecahkan oleh seorang pakar dalam bidangnya [3]. Sistem pakar (expert system) adalah sistem yang berusaha mengadopsi pengetahuan manusia ke komputer, agar komputer dapat menyelesaikan masalah seperti yang biasa dilakukan oleh para ahli. Sistem pakar yang baik dirancang agar dapat menyelesaikan suatu permasalahan tertentu dengan meniru kerja dari para ahli [4]. Istilah sistem pakar berasal dari istilah knowledge-based expert system. Istilah ini muncul karena untuk memecahkan masalah, sistem pakar menggunakan pengetahuan seorang pakar yang dimasukkan ke dalam komputer. Seseorang yang bukan pakar menggunakan sistem pakar untuk meningkatkan kemampuan pemecahan masalah, sedangkan seorang pakar [5]

Untuk pembangun sistem pakar maka komponen-komponen dasar meliputi (user interface) yang merupakan sarana komunikasi antar pemakai dan system. Kemudian basis pengetahuan (knowledge base) adalah basis pengetahuan yang dimiliki oleh seorang pakar yang merupakan bagian terpenting dalam Sistem Pakar, dan yang terakhir Mesin inferensi (Inference Engine) sebagai pembangkit inferensi analisa dari sebuah masalah tertentu yang selanjutnya mencari jawaban dari kesimpulan terbaik [6]. Sejumlah teori telah ditemukan untuk menyelesaikan ketidakpastian, salah satu diantaranya adalah probabilitas Bayes (Bayesian probalility). Probabilitas menunjukkan kemungkinan sesuatu akan terjadi atau tidak [7].

Teorema Bayes digunakan untuk menghitung probabilitas terjadinya suatu peistiwa berdasarkan pengaruh yang didapat dari hasil observasi. Teorema ini menerangkan hubungan antara probabilitas terjadinya peristiwa A dengan syarat peristiwa B telah terjadi dan probabilitas terjadinya peristiwa B dengan syarat peristiwa A telah terjadi. Teorema ini didasarkan pada prinsip bahwa tambahan informasi dapat memperbaiki probabilitas [8]. Penelitian sistem pakar pernah dilakukan Perbaikan kerusakan disalah satu Bengkel Ahass $07721 \mathrm{Cv}$. Anugerah Kencana Motor di kota Lubuklinggau oleh Saputra J and Karman J [9], mekanik yang menangani kerusakan sepeda motor masih mempergunakan keterampilan hidup yang dimiliki untuk menganalisis kerusakan yang terjadi pada sepeda motor yang ditangani sehingga hal itu menyebabkan penanganan membutuhkan waktu yang lama sehingga menyebabkan ketidakpuasan pada pengerjaan yang menjadi permasalahan bagi pemilik motor. Adanya kendala yang terjadi pada Bengkel Ahass $07721 \mathrm{Cv}$. Anugerah Kencana Motor di kota Lubuklinggau yang mendasari penulis untuk membuat sebuah Sistem Pakar dengan menggunaka Metode Teorema Bayes yang dapat menganalisis jenis kerusakan pada sepeda motor sesuai pendapat pakar atau dari sumber yang dapat digunakan oleh Mekanik.

Metode Bayes merupakan metode yang baik di dalam mesin pembelajaran berdasarkan data training dengan menggunakan probabilitas bersyarat sebagai dasarnya. Metode ini pernah digunakan dalam penelitian terdahulu oleh Putra I. P. W [10]. Tujuan penelitiannya untuk mempermudah menemukan kerusakan pada AC dengan memprediksi probabilitas berdasarkan pengalaman di masa sebelumnya. Dengan adanya kemajuan dan perkembangan teknologi yang semakin pesat, dikembangkan suatu teknologi yang mampu mengimplementasikan teorema bayes untuk menganalisa kerusakan pada Air Conditioner ruangan berbasis android.

Sedangkan tujuan dari penelitian adalah: untuk menyelesaikan permasalahan bagi pengguna PC. Salah satu permasalahannya adalah mengalami kerusakan, sehinnga sangat menghabat pekerjaan. Oleh karena itu maka penelitian ini akan membangun sebuah sistem untuk membantu pengguna dalam perbaikan PC. Pengguna akan sangat dimudahkan dalam melakukan perbaikan yaitu hanya dengan cara berkonsultasi lewat website tanpa harus pergi langsung ke teknisi. Dengan begitu pengguna akan menghemat waktu dan efisiensi biaya perbaikan.

\section{METODE PENELITIAN}

Metodologi penelitian ini akan menampilkan tentang kerangka kerja penelitian yang akan dilakukan. Sebelum melakukan penelitian maka diperlukan suatu metode atau tahapan yang harus dilakukan untuk melakukan penelitian. Hal ini bermaksud agar hasil yang diperoleh dari penelitian ini dapat bermanfaat dengan maksimal.

\subsection{Algoritma Teorema Bayes}

Algoritma ini menggunakan metode probabilitas dan statistik yang dikemukan oleh seorang ilmuwan Inggris

Thomas Bayes. Algoritma Naive Bayes digunakan karena algoritma ini merupakan teknik prediksi berbasis probalitistik sederhana yang berdasarkan pada penerapan teorema bayes (aturan bayes) dengan 
asumsi independensi (ketidak tergantungan) yang kuat (naif). Dengan kata lain, dalam naive bayes model yang digunakan adalah model fitur independent.

$p\left(H_{i} \mid E\right)=\frac{p\left(H_{i} \mid E\right) x p\left(H_{i}\right)}{\sum_{k=1}^{n} p\left(\llbracket E \mid H \rrbracket_{k}\right) x p\left(H_{k}\right)}$

Dimana:

$\mathrm{P}(\mathrm{Fi} \mid \mathrm{E})$ : Probabilitas akhir bersyarat (conditional probability) suatu hipotesis Fi terjadi jika diberikan bukti (evidence) E terjadi.

$\mathrm{P}(\mathrm{E} \mid \mathrm{Fi})$ : Probabilitas sebuah bukti E terjadi akan mempengaruhi hipotesis Fi.

$\mathrm{P}(\mathrm{Fi})$ : Probabilitas awal (priori) hipotesis Fi terjadi tanpa memandang bukti apapun.

$\mathrm{P}(\mathrm{E})$ : Probabilitas awal (priori) bukti E terjadi tanpa memandang hipotesis / bukti yang lain.

Metode Teorema Bayes ini memiliki beberapa kelebihan yaitu:

(1) Bayesian filter memiliki komputasi yang mudah. (2) Bayesian memeriksa data secara keseluruhan yaitu memeriksa token di database spam maupun legitimate. (3)Bayesian filtering termasuk dalam supervised learning yaitu secara otomatis akan melakukan proses learning dari data yang masuk. (4)Bayesian filtering cocok diterapkan di level aplikasi individual user. (5) Bayesian filtering cocok diterapkan pada binary class yaitu klasifikasi ke dalam dua kelas. (6) Metode Bayes merupakan metode yang baik di dalam mesin pembelajaran berdasarkan data training, dengan menggunakan probabilitas bersyarat sebagai dasarnya.

Metode Bayes merupakan satu metode yang digunakan

untuk menghitung ketidakpastian data menjadi data yang pasti dengan membandingkan antara ya dan tidak.[13]

Flowchart merupakan penggambaran secara grafik dari langkah-langkah dan urutan prosedur dari suatu program kerja secara keseluruhan menggunakan metode Teorema Bayes mulai dari awal sampe akhir prosesnya

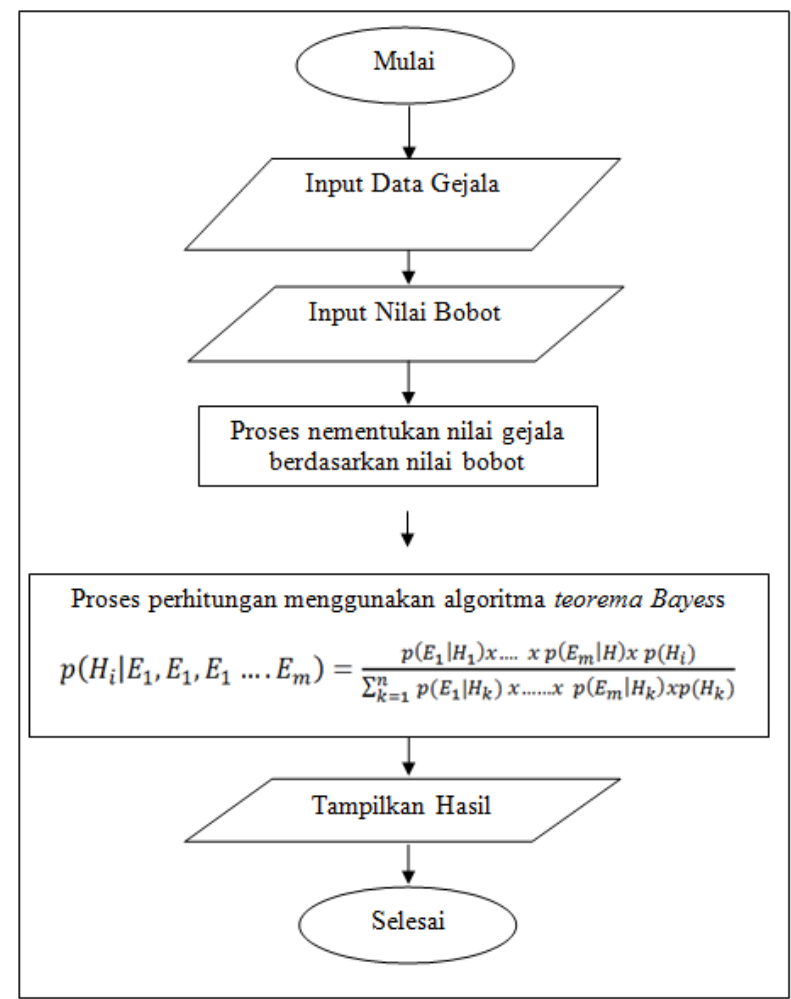

Gambar 1 Flowchart Sistem pakar Kerusakan PC

Gambar diatas menunjukan langkah-langkah dalam pengembangan sistem pakar kerusakan PC menggunakan metode Teorema Bayes dimulai dari pakar yang menginput data gejala kerusakan yang 
diperoleh dari data penelitian. Kemudian pakar juga akan menginput nilai bobot berdasarkan gejala yang kemudian akan diproses dengan nilai gejala untuk menghasilkan nilai bobot yang mendasar. Setelah semua nilai bobot telah dihitung maka data bobot tersebut akan diproses dengan metode teorema bayes untuk menghasilkan sebuah nilai keputusan dalam menentukan kerusakan PC. Setelah proses perhitungan telah dilakukan akan menghasilkan hasil berupa solusi kerusakan dengan nilai tingkat keyakinan dalam persen. Dengan begitu pengguna akan dapat mengetahui kerusakan pada komputernya.

\subsection{Data Kerusakan PC}

Knowledge Base berasal dari penelitian kerusakan PC yang pernah ditangani oleh Divisi Teknisi Komputer STMIK Triguna Dharma Medan yang berasal dari 2 tahun terakhir yaitu dari tahun 2018 2020. Intensitas kerusakannya sendiri lumayan tinggi, dengan begitu memberi manfaat sebagai bahan refrensi data. Datanya sendiri didapat dari seorang pakar Teknisi komputer yang bernama Bpk Edi Susanto, S.Kom selaku Kepala Divisi Teknisi Komputer yang telah menjadi teknisi komputer di STMIK Triguna Dharma yang telah berpengalaman selama 10 tahun.

\subsubsection{Jenis Kerusakan Komputer}

Jenis kerusakan PC berdasarkan data yang saya peroleh dari penelitian pada laboratorium komputer STMIK Triguna Dharma Medan digolongkan menjadi 7 katagori kerusakan yaitu kerusakan pada Motherboard, Graphic Card, Software, Monitor, Power Supply, RAM (Random Acces Memory).

Tabel 1.Tabel Jenis Kerusakan PC

\begin{tabular}{|c|c|c|}
\hline NO & $\begin{array}{c}\text { Kode } \\
\text { Kerusakan }\end{array}$ & Jenis Kerusakan \\
\hline 1 & K001 & Motherboard \\
\hline 2 & K002 & Graphic Card \\
\hline 3 & K003 & Software \\
\hline 4 & K004 & Monitor \\
\hline 5 & K005 & Power Supply \\
\hline 6 & K006 & RAM \\
\hline 7 & K007 & Hardisk \\
\hline
\end{tabular}

Jenis kerusakan dari tabel ini, di katagorikan berdasarkan gejala-gejala yang sering terjadi yang telah diverifikasi oleh pakar dan refrensi dari beberapa jurnal. Maka didapatlah 7 kategori kerusakan dimana keseluruhan kerusakan mencakup komponen dalam sebuah Komputer.

\subsubsection{Gejala Kerusakan Pada PC}

Setelah melakukan penelitian dan pengumpulan data di kampus STMIK Triguna Dharma Medan Divisi Teknisi Komputer saya membuat tabel yang mencakup gejala-gejala kerusakan PC yang didapati dari setiap kerusakan. Berikut table kerusakan PC

Tabel 2.Tabel Gejala Kerusakan PC

\begin{tabular}{|c|c|l|}
\hline NO & $\begin{array}{c}\text { Kode } \\
\text { Gejala }\end{array}$ & \multicolumn{1}{|c|}{ Jenis Gejala } \\
\hline 1 & GJ001 & $\begin{array}{l}\text { CPU Mati Tetapi Lampu Indikator Powernya } \\
\text { Menyala }\end{array}$ \\
\hline 2 & GJ002 & $\begin{array}{l}\text { PC Hidup Normal Dan Tidak Lama Mati } \\
\text { Tiba-tiba }\end{array}$ \\
\hline 3 & GJ003 & $\begin{array}{l}\text { CPU Hidup Normal Tetapi Monitor Mati } \\
\text { Total }\end{array}$ \\
\hline 4 & GJ004 & $\begin{array}{l}\text { Tampilan PC Pada Layar Monitor Muncul } \\
\text { Bercak }\end{array}$ \\
\hline 5 & GJ005 & PC Hang / Not Responding \\
\hline 6 & GJ006 & $\begin{array}{l}\text { CPU Hidup Tetapi Kipas Prosesor Hidup- } \\
\text { Mati }\end{array}$ \\
\hline 7 & GJ007 & Bluescreen \\
\hline
\end{tabular}




\begin{tabular}{|c|c|l|}
\hline 8 & GJ008 & Tampil pemberitahuan bootable not Found \\
\hline 9 & GJ009 & Tampil Operting System Not Found \\
\hline 10 & GJ010 & Tampilan Pada Layar Monitor Hanya Putih \\
\hline 11 & GJ011 & Tampilan pada monitor berkedip-kedip \\
\hline 12 & GJ012 & $\begin{array}{l}\text { Tampilan Pada Monitor Warnanya Berubah- } \\
\text { ubah }\end{array}$ \\
\hline 13 & GJ013 & Muncul file tidak dikenal / Shortcut \\
\hline 14 & GJ014 & PC Mengalami Restart Berulang \\
\hline 15 & GJ015 & Aplikasi Keluar Sendiri / Crash \\
\hline 16 & GJ016 & Kinerja PC berjalan lambat \\
\hline 17 & GJ017 & $\begin{array}{l}\text { Setiap Startup selalu meminta pengaturan } \\
\text { waktu pada Bios }\end{array}$ \\
\hline 18 & GJ018 & $\begin{array}{l}\text { CPU Mati Total Lampu Indikator Power } \\
\text { Tidak Hidup }\end{array}$ \\
\hline
\end{tabular}

Tabel diatas merupakan kode gejala dari setiap kerusakan pada PC, kemudian dari gejala tersebut kita dapat mengidentifikasi dan mempertimbangkan kerusakannya. Daftar gejala pada tabel ini merupakan data yang berhasil dikumpulkan dari setiap kerusakan PC pada Divisi Komputer STMIK Triguna Dharma Medan.

\subsubsection{Identifikasi Kerusakan Berdasarkan Gejala}

Identifikasi kerusakan ini berdasarkan dari pengamatan seorang pakar yang melihat dari gejalagejala yang ditemukan dalam melakukan perbaikan komputer dimana gejala tersebut mewakili komponen-komponen yang mengalami kerusakan. Berikut tabel jenis kerusakan beserta gejala yang dialami :

Tabel 4.Tabel Identifikasi Kerusakan Berdasarkan Gejala

\begin{tabular}{|c|c|}
\hline $\begin{array}{c}\text { Jenis } \\
\text { Kerusakan }\end{array}$ & Gejala \\
\hline \multirow{4}{*}{ Motherboard } & GJ002 \\
\hline & GJ008 \\
\hline & GJ007 \\
\hline & GJ017 \\
\hline \multirow{4}{*}{ Kartu Grafis } & GJ004 \\
\hline & GJ011 \\
\hline & GJ012 \\
\hline & GJ016 \\
\hline \multirow{3}{*}{ Monitor } & GJ003 \\
\hline & GJ010 \\
\hline & GJ011 \\
\hline \multirow{8}{*}{ Software } & GJ010 \\
\hline & GJ008 \\
\hline & GJ002 \\
\hline & GJ005 \\
\hline & GJ007 \\
\hline & GJ013 \\
\hline & GJ014 \\
\hline & GJ016 \\
\hline
\end{tabular}




\begin{tabular}{|c|c|}
\hline \multirow{4}{*}{ Power Supply } & GJ015 \\
\cline { 2 - 2 } & GJ009 \\
\cline { 2 - 2 } & GJ001 \\
\cline { 2 - 2 } & GJ014 \\
\hline \multirow{4}{*}{ RAM } & GJ018 \\
\cline { 2 - 2 } & GJ005 \\
\cline { 2 - 2 } & GJ06 \\
\cline { 2 - 2 } & GJ014 \\
\cline { 2 - 2 } & GJ007 \\
\cline { 2 - 2 } & GJ018 \\
\hline \multirow{4}{*}{ Hardisk } & GJ005 \\
\cline { 2 - 2 } & GJ008 \\
\cline { 2 - 2 } & GJ009 \\
\cline { 2 - 2 } & GJ016 \\
\hline
\end{tabular}

Tabel diatas menerangkan kerusakan pada PC dapat diidentifikasi berdasarkan gejala-gejala kerusakan yang terdapat dari PC tersebut. Pada dasarnya gejala kerusakan pada setiap PC hampir seluruhnya sama walau berbeda merk. Karena dasar gejala kerusakan komputer sendiri terletak pada komponen yang terdapat dalam Sebuah PC.

\subsubsection{Solusi Kerusakan}

Solusi kerusakan merupakan tujuan dari penelitian ini. Hasil berupa solusi perbaikan ini akan sangat bermanfaat bagi pengguna. dimana setiap kerusakan pada PC akan diberikan Solusi dari permasalahannya. Solusi kerusakan diperoleh setelah melakukan pengumpulan data kerusakan dan gejala beserta solusi dari kasus kerusakan yang besumber dari seorang pakar yang telah berpengalaman. Pakar dapat mengambil keputusan dalam menentukan kerusakan dan solusinya dari gejala-gejala yang berada pada PC tersebut. Oleh karena itu pengumpulan data kerusakan PC pada Divisi Teknisi Komputer STMIK Triguna Dharma Medan telah mencakup solusi perbaikannya.

\subsubsection{Probabilitas}

a. Kerusakan K001 (Motherboard)
GJ002 $=0.25$
$\mathrm{GJ} 007=0.50$
GJ008 $=0.25$
$\mathrm{GJ} 017=0.75$
b. Kerusakan K002 (Graphic Card)

\begin{tabular}{|c|c|c|c|c|}
\hline GJ004 & $=0.67$ & GJ011 $=0.67$ & GJ012 $=0.67$ & GJ016 $=0.17$ \\
\hline c. & Kerusa & 3 (Software) & & \\
\hline GJ002 & $=0.08$ & GJ005 $=0.4$ & GJ007 $=0.08$ & GJ008 $=0.08$ \\
\hline GJ009 & $=0.23$ & GJ010 $=0.08$ & GJ013 $=0.31$ & GJ014 $=0.08$ \\
\hline GJ015 & $=0.15$ & GJ016 $=0.38$ & & \\
\hline
\end{tabular}

d. Kerusakan K004 (Monitor)
GJ003 $=0.2$
GJ010 $=0.50$
GJ011 $=0.50$
e. Kerusakan K005 (Power Supply)
GJ001 $=0.29$
GJ014 $=0.14$
GJ018 $=0.71$
f. Kerusakan K006 (RAM)
GJ001 $=0.13$
GJ005 $=0.13$
$\mathrm{GJ} 014=0.14$
GJ018 $=0.71$
GJ006 $=0.75$
$\mathrm{GJ} 007=0.13$
g. Kerusakan K007 (Hardisk)
GJ005 $=0.33$
GJ008 $=0.56$
GJ009 $=0.11$
GJ016 $=0.33$ 
Tabel 5 Nilai Bobot Probabilitas

\begin{tabular}{|c|c|}
\hline Bilangan & Nilai \\
\hline Tidak Pasti & $0.1-0.3$ \\
\hline Kurang Pasti & $0.4-0.6$ \\
\hline Pasti & $0.7-0.9$ \\
\hline Sangat Pasti & 1 \\
\hline
\end{tabular}

Nilai bobot diperoleh dari rekomendasi pakar yaitu Kepala Bidang Divisi Teknisi Komputer STMIK Triguna Dharma Medan serta beberapa jurnal dari penelitian terdahulu.

\section{ANALISA DAN HASIL}

Data kerusakan PC yang telah dikumpulkan kemudian diambil sebuah sample kerusakan dimana terdapat 20 pilihaan gejala yang di berikan kepada pengguna didapat hasil jawaban sebagai berikut:

Tabel 6 Contoh Kasus Gejala

\begin{tabular}{|l|l|c|}
\hline $\begin{array}{c}\text { Kode } \\
\text { Gejala }\end{array}$ & \multicolumn{1}{|c|}{ Pertanyaan Berdasarkan Gejala } & Pilih \\
\hline GJ001 & $\begin{array}{l}\text { CPU Mati Tetapi Lampu Indikator } \\
\text { Powernya Menyala }\end{array}$ & \\
\hline GJ002 & $\begin{array}{l}\text { PC Hidup Normal Dan Tidak Lama Mati } \\
\text { Tiba-tiba }\end{array}$ & \\
\hline GJ003 & $\begin{array}{l}\text { CPU Hidup Normal Tetapi Monitor Mati } \\
\text { Total }\end{array}$ & \\
\hline GJ004 & Tampilan PC Pada Layar Monitor Acak & \\
\hline GJ005 & PC Hang / Not Responding & $\sqrt{ }$ \\
\hline GJ006 & $\begin{array}{l}\text { CPU Hidup Tetapi Kipas Prosesor Hidup- } \\
\text { Mati }\end{array}$ & \\
\hline GJ007 & Bluescreen & $\sqrt{ }$ \\
\hline GJ008 & Tampil pemberitahuan bootable not Found & \\
\hline GJ009 & Tampil Operting System Not Found & \\
\hline GJ010 & Tampilan Pada Layar Monitor Hanya Putih & \\
\hline GJ011 & Tampilan pada monitor berkedip-kedip & \\
\hline GJ012 & $\begin{array}{l}\text { Tampilan Pada Monitor Warnanya } \\
\text { Berubah-ubah }\end{array}$ & \\
\hline GJ013 & Muncul file tidak dikenal / Shortcut & $\sqrt{ }$ \\
\hline GJ014 & PC Mengalami Restart Berulang & \\
\hline GJ015 & Aplikasi Keluar Sendiri / Crash & $\sqrt{ }$ \\
\hline GJ016 & Kinerja PC berjalan lambat & \begin{tabular}{l} 
\\
\hline GJ017 \\
Wetiap Startup selalu meminta pengaturan
\end{tabular} \\
\hline GJ018 & $\begin{array}{l}\text { CPU Mati Total Lampu Indikator Power } \\
\text { Tidak Hidup }\end{array}$ & \\
\hline
\end{tabular}

(sumber :Divisi Teknisi Komputer STMIK Triguna Dharma)

Dari tabel contoh kasus diperoleh data kerusakan PC dengan memilih gejala GJ005, GJ007, GJ013, GJ015, GJ016. Contoh ini diperoleh dari salah satu kerusakan PC di Kampus STMIK Triguna Dharma Medan. Maka dilakukan perhitungan menggunakan Teorema Bayes untuk tiap gejala.

Langkah pertama : mendefenisikan terlebih dahulu nilai probabilitas dari tiap evidence untuk tiap hipotesis berdasarkan data sampel yang ada menggunakan rumus probabilitas Bayes. 
$\mathrm{P}(\mathrm{A} / \mathrm{B})=(\mathrm{p}(\mathrm{B} \cap \mathrm{A})) /(\mathrm{P}(\mathrm{B}))$

a. Kerusakan pada K001 (Motherboard)

$\mathrm{GJ} 007=p(E \mid H 1)=0.50$

$\mathrm{GJ} 016=p(E \mid H 2)=0.75$

b. Kerusakan pada K002 (Graphic Card)

$\mathrm{GJ} 016=p(E \mid H 1)=0.17$

c. Kerusakan pada K003 (Software)

$\mathrm{GJ} 005=p(E \mid H 1)=0.4$

$\mathrm{GJ} 07=p(E \mid H 2)=0.08$

$\mathrm{GJ} 13=p(E \mid H 3)=0.31$

$\mathrm{GJ} 015=p(E \mid H 4)=0.15$

$\mathrm{GJ} 016=p(E \mid H 5)=0.38$

d. Kerusakan Pada K006 (RAM)

$\mathrm{GJ} 005=p(E \mid H 1)=0.13$

$\mathrm{GJ} 007=p(E \mid H 2)=0.13$

e. Kerusakan pada K007 (Hardisk)

$\mathrm{GJ} 005=p(E \mid H 1)=0.33$

$\mathrm{GJ} 016=p(E \mid H 2)=0.33$

Langkah kedua: menjumlahkan nilai probabilitas dari tiap evidence untuk masing-masing hipotesis berdasarkan data sampel.

$\sum_{G n}^{n} \quad k=1=G 1+\cdots+G n$

a. Kerusakan pada K001 (Motherboard)

GJ007 $=\mathrm{p}(\mathrm{E} \mid \mathrm{H} 1)=0.50 \quad$ GJ016=p(E $\mid \mathrm{H} 2)=0.75$

$\sum_{-} G n^{\wedge} n$ \# $\llbracket k=1=0.50+0.75 \rrbracket=1.25$

b. Kerusakan pada K002 (VGA)

GJ002 $=\mathrm{p}(\mathrm{E} \mid \mathrm{H} 1)=0.17$

$\sum_{-} G n^{\wedge} n$ 政

c. Kerusakan pada K003 (Software)

GJ005 $=\mathrm{p}(\mathrm{E} \mid \mathrm{H} 1)=0.4 \quad$ GJ007 $=\mathrm{p}(\mathrm{E} \mid \mathrm{H} 2)=0.08$

GJ013 $=\mathrm{p}(\mathrm{E}$ H3 $)=0.31 \quad \mathrm{GJ} 015=\mathrm{p}(\mathrm{E}) \mathrm{H} 4)=0.15$

GJ016 $=\mathrm{p}(\mathrm{E}$ H5) $=0.38$

$\sum \_G n^{\wedge} n$ 鴊 $\llbracket k=1=0.4+0.08+0.31+0.15+0.38 \rrbracket=1.32$

d. Kerusakan pada K006 (RAM)

GJ005 $=\mathrm{p}(\mathrm{E} \mid \mathrm{H} 1)=0.13 \quad$ GJ007 $=\mathrm{p}(\mathrm{E} \mid \mathrm{H} 2)=0.13$

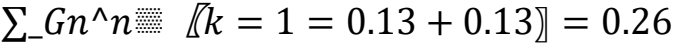

e. Kerusakan pada K007 (Hardisk)

GJ005 $=\mathrm{p}(\mathrm{E} \mid \mathrm{H} 1)=0.33$ GJ016=p(E $\mid \mathrm{H} 2)=0.33$

$\sum \_G n^{\wedge} n$ 整 $\llbracket[k=1=0.33+0.33 \rrbracket=0.66$

Langkah ketiga: mencari nilai probabilitas hipotesis $\mathrm{H}$ tanpa memandang evidence apapun bagi masingmasing hipotesis.

$P(H 1)=(P(E \mid H 1)) /\left(\sum_{-}(k-n)^{\wedge} n\right.$ 
a. Kerusakan pada K001 (Motherboard)

GJ007 $=\mathrm{P}(\mathrm{H} 1)=0.50 / 1.25=0.4$

$\mathrm{GJ} 016=\mathrm{P}(\mathrm{H} 2)=0.75 / 1.25=0.6$

b. Kerusakan pada K002 (Graphic Card)

$\mathrm{GJ} 016=\mathrm{P}(\mathrm{H} 1)=0.17 / 0.17=1$

c. Kerusakan pada K003 (Software)

GJ005 $=\mathrm{P}(\mathrm{H} 1)=0.4 / 1.32=0.003$

GJ007 $=\mathrm{P}(\mathrm{H} 2)=0.08 / 1.32=0.0006$

$\mathrm{GJ} 013=\mathrm{P}(\mathrm{H} 3)=0.31 / 1.32=0.06$

GJ015 $=\mathrm{P}(\mathrm{H} 4)=0.15 / 1.32=0.11$

$\mathrm{GJ} 016=\mathrm{P}(\mathrm{H} 5)=0.38 / 1.32=0.28$

d. Kerusakan pada K006 (RAM)

$\mathrm{GJ} 005=\mathrm{P}(\mathrm{H} 1)=0.13 / 0.26=0.5$

$\mathrm{GJ} 007=\mathrm{P}(\mathrm{H} 2)=0.13 / 0.26=0.5$

e. Kerusakan pada K007 (Hardisk)

GJ005 $=\mathrm{P}(\mathrm{H} 1)=0.33 / 0.66=0.5$

$\mathrm{GJ} 016=\mathrm{P}(\mathrm{H} 2)=0.33 / 0.66=0.5$

Langkah keempat: mencari nilai probabilitas hipotesis memandang evidence dengan cara mengalikan nilai probabilitas evidence awal dengan nilai nilai probabilitas hipotesis tanpa memandang evidence dan menjumlahkan hasil perkalian bagi masing-masing hipotesis :

$\sum_{k=n}^{n}$ Bayes $=p(H 1) * p(E \mid H 1)+\cdots+p(H i) * p(E \mid H i)$

a. Kerusakan pada K001 (Motherboard)

$\Sigma_{-}(k=2)^{\wedge} 2$ (Bayes $\left.=(0.50 * 0.4)+(0.75 * 0.6)=0.65\right)$

b. Kerusakan pada K002 (VGA)

$\sum_{-}(k=1)^{\wedge} 1$ (Bayes $\left.=(0.17 * 1)=0.17\right)$

c. Kerusakan pada K003 (Software)

$\sum_{-}(k=5)^{\wedge} 5$ 『Bayes

$$
\begin{aligned}
& =(0.4 * 0.003)+(0.08 * 0.0006)+(0.31 * 0.06)+(0.15 * 0.11)+(0.38 * 0.28)) \\
& =0.14
\end{aligned}
$$

d. Kerusakan pada K006 (RAM)

$\sum_{-}(k=2)^{\wedge} 2$ 【Bayes $=(0.13 * 0.5)+(0.13 * 0.5) \rrbracket=0.13$

e. Kerusakan pada K007 (Hardisk)

$$
\sum_{-}(k=2)^{\wedge} 2 \text { ॠBayes }=(0.33 * 0.5)+(0.33 * 0.5) \rrbracket=0.33
$$

Langkah kelima:mencari nilai $\mathrm{P}(\mathrm{Hi} \mid \mathrm{E})$ atau probabilitas hipotesis Hi benar jika diberikan evidence $\mathrm{E}$.

$\mathrm{P}(\mathrm{Hi} \mid \mathrm{Ei})=(p(H i) * p(E \mid H i)) /\left(\sum_{-}(k-n)^{\wedge} n\right) \ldots$

a. Kerusakan pada K001 (Motherboard)

$\mathrm{p}(\mathrm{H} 1 \mid \mathrm{E})=(0.50 * 0.4) /(0.65)=0.30$

$\mathrm{p}(\mathrm{H} 2 \mid \mathrm{E})=(0.75 * 0.6) /(0.65)=0.69$

b. Kerusakan pada K002 (VGA) 
$\mathrm{p}(\mathrm{H} 1 \mid \mathrm{E})=(0.17 * 1) / 0.17=1$

c. Kerusakan pada K003 (Software)

$\mathrm{p}(\mathrm{H} 1 \mid \mathrm{E})=(0.4 * 0.003) / 0.14=0.008$

$\mathrm{p}(\mathrm{H} 1 \mid \mathrm{E})=(0.19 * 1.35) / 4.26=0.06$

$\mathrm{p}(\mathrm{H} 1 \mid \mathrm{E})=(0.08 * 0.0006) / 0.14=0.0003$

$\mathrm{p}(\mathrm{H} 1 \mid \mathrm{E})=(0.15 * 0.11) / 0.14=0.11$

$\mathrm{p}(\mathrm{H} 1 \mid \mathrm{E})=(0.38 * 0.28) / 0.14=0.76$

d. Kerusakan pada K006 (RAM)

$\mathrm{p}(\mathrm{H} 1 \mid \mathrm{E})=(0.13 * 0.5) / 0.13=0,5$

$\mathrm{p}(\mathrm{H} 1 \mid \mathrm{E})=(0.13 * 0.5) / 0.13=0.5$

e. Kerusakan pada K007 (Hardisk)

$\mathrm{p}(\mathrm{H} 1 \mid \mathrm{E})=(0.33 * 0.5) / 0.33=0.5$

$\mathrm{p}(\mathrm{H} 1 \mid \mathrm{E})=(0.33 * 0.5) / 0.33=0.5$

Langkah ke enam: mencari nilai kesimpulan sari Teorema Bayes dengan cara mengalikan nilai probabilitas evidence awal atau $\mathrm{P}(\mathrm{E} \mid \mathrm{Hi})$ dengan nilai hipotesis Hi benar jika diberikan evidence $\mathrm{E}$ atau $\mathrm{P}(\mathrm{Hi} \mid \mathrm{E})$ dan menjumlahkan hasil perkalian.

$\Sigma_{-}(k=n)^{\wedge} n$ \#

a. Kerusakan pada Motherboard $=\mathrm{K} 001$

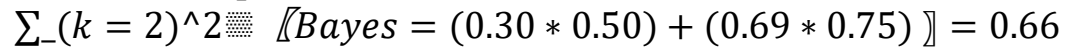

b. Kerusakan pada $V G A=\mathrm{K} 002$

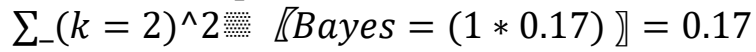

c. Kerusakan pada Software $=\mathrm{K} 003$

$\sum_{-}(k=2)^{\wedge} 2$ 『Bayes

$$
\begin{aligned}
& =(0.008 * 0.003)+(0.06 * 0.0006)+(0.0003 * 0.06)+(0.11 * 0.11)+(0.76 \\
& * 0.28) \rrbracket=0.22
\end{aligned}
$$

d. Kerusakan pada $R A M=\mathrm{K} 006$

$\Sigma_{-}(k=2)^{\wedge} 2$ 政 $\llbracket$ Bayes $=(0.5 * 0.5)+(0.5 * 0.5) \rrbracket=0.50$

e. Kerusakan pada Hardisk $=$ K007

$\Sigma_{-}(k=2)^{\wedge} 2$ 『Bayes $=(0.5 * 0.5)+(0.5 * 0.5) \rrbracket=50$

Dari proses perhitungan di atas, maka dapat diketahui bahwa PC mengalami kerusakan pada Software dengan nilai keyakinan 00.66 atau $66 \%$. Setelah mendapatkan hasil dari proses algoritma, maka dapat disimpulkan solusi untuk jenis kerusakan Sofware.

Tabel 7 Solusi Kerusakan dari Contoh Kasus

\begin{tabular}{|c|c|l|}
\hline Kerusakan & $\begin{array}{c}\text { Kode } \\
\text { Gejala }\end{array}$ & \multicolumn{1}{c|}{ Solusi } \\
\hline Software & GJ005 & $\begin{array}{l}\text { 1.Cek apakah software yang di-install dalam } \\
\text { keadaan baik atau corupt jika corupt penyebabnya } \\
\text { adalah virus, patikan komputer telah terinstal } \\
\text { antivirus yang baik. }\end{array}$ \\
\hline
\end{tabular}




\begin{tabular}{|c|c|l|}
\hline & GJ014 & $\begin{array}{l}\text { 2.Jika tejadi bluescreen biasanya driver yang tidak } \\
\text { cocok jadi masuk safe mode dan buang semua } \\
\text { driver yang tidak diperlukan, lalu setelah semua } \\
\text { driver diuninstal, restart PC Anda. } \\
\text { GJ016 }\end{array}$ \\
& & 3.Instal ulang aplikasinya atau sistem operasinya \\
\hline
\end{tabular}

Tabel diatas menyimpulkan hasil solusi dari proses perhitungan yang panjang didapatilah sebuah hasil yang merupakan solusi dari kerusakan PC.

Dengan begitu user mengetahui identifikasi kerusakan PCnya dari gejala kerusakan yang diinputnya kedalam sistem, kemudian pengguna dapat menerapkan solusi yang dihasilkan ini. Dimana Kerusakan PC di identifikasi mengalami kerusakan pada softwarenya. Sistem pakar ini sangat membantu dalam melakukan perbaikan tanpa perlu lagi pergi ke teknisi komputer.

\section{KESIMPULAN}

Berdasarkan hasil analisis dan pengujian dari Sistem Pakar Kerusakan dengan Metode Teorema Bayes pada STMIK Triguna Dharma Medan kepada pengguna maka dapat memudahkan para pengguna PC untuk mendeteksi kerusakan PCnya sendiri sebelum membawa ke Teknisi Komputer, sehingga pengguna dapat mengurangi biaya perbaikan dan menghemat waktu dengan hanya konsultasi lewat website. Kemudian dengan aplikasi yang dirancang pada Sistem Pakar Mendeteksi Kerusakan PC Dengan Metode Teorema Bayes pada Kampus STMIK Triguna Dharma Medan menggunakan web mempunyai tingkat kenyakinan yang baik dalam menentukan kerusakan dan memberikan solusi pada kerusakan PC.

\section{UCAPAN TERIMA KASIH}

Saya aturkan banyak terima kasih kepada orang tua saya, para rekan dosen serta staf STMIK Triguna Dharma Medan yang membantu keberhasilan penelitian ini.Semoga penelitian ini bermafaat bagi banyak orang.

\section{REFERENSI}

[1] Yuwono, D.T., Fadlil, A., and Sunardi. 2017. Penerapan Metode Forward Chaining Pada Sistem Pakar Kerusakan Komputer., 4(2), pp. 136-145.

[2] Omolaye, O.P., 2017. A Holistic Review of Soft Computing Techniques. Applied and Computational Mathematics, 6(2), 93. http://doi.org/10.11648/j.acm.20170602.15

[3] Anggara, G., Pramayu, G., 2016. Membangun sistem pakar menggunakan teorema bayes untuk mendiagnosa penyakit paru-paru. Seminar Nasional Teknologi Informasi Dan Multimedia,pp. 79-84.

[4] Russari, I,. 2016. Sistem Pakar Diagnosa Penyakit Batu Ginjal. Jurnal Riset Komputer (JURIKOM), (3),pp.18-22.

[5] Sihotang, H. T., Panggabean, E., \& Zebua, H., 2018. Sistem Pakar Mendiagnosa Penyakit Herpes Zoster Dengan Menggunakan Metode Teorema Bayes. Journal Of Informatic Pelita Nusantara, 3(1),pp.33-40. Retrieved from http://ejurnal.pelitanusantara.ac.id/index.php/JIPN/article/view/284/181

[6] Qamaruzzaman, M.H., and Sam'ani., 2016. Sistem Pakar Untuk Mendiagnosa Penyakit Mata Pada Manusia Menggunakan Teorema Bayes. Indonesian Journal on Networking and Security, 5(4),pp.711.

[7]Rido, A., \& Wardhani, R., 2017. Sistem Pakar Mendiagnosa Penyakit Pada Unggas Dengan Metode Teorema Bayes Berbasis Web. Jouticla, 3(2),pp.51-56.

[8] Marselena, S., Labellapansa, A., \& Syukur., A. 2018. Penalaran Berbasis Aturan Untuk Diagnosa Awal Penyakit Anjing Menggunakan Teorema Bayes. Jurnal RESTI (Rekayasa Sistem Dan Teknologi Informasi), 2(2), pp.530-535. http://doi.org/https://doi.org/10.29207/resti.v2i2.454

[9] Karman, J., Saputra, J. 2018. Sistem Pakar Diagnosa Kerusakan Sepeda Motor Bebek Dengan Metode Teorema Bayes., Musirawas, S. No Title, 3(1), pp.58-64.

[10] Savitri, P., \& Hadi, T. 2018. Implementasi Metode Forward Chaining Dalam Sistem Pendeteksi Kerusakan Hardware Pada Komputer Dan Laptop, 9(1), pp.623-632. 
[11] Putra, I. P. W., 2016. Implementasi Teorema Bayes Untuk Menganalisa Kerusakan Pada Air Conditioner Ruangan Berbasis Android, (1),pp.6-7.

[12] Sidauruk A., Pujianto A., 2017. Sistem Pakar Diagnosa Penyakit Tanaman Kelapa Sawit Menggunakan Teorema Bayes. Jurnal Ilmiah DASI Vol. 18 No. 1, Vol. 18, pp.51-56.

[13] Nababan, F.J., 2017. Sistem pakar mendiagnosa kelahiran bayi prematur dengan menggunakan metode teorema bayes. Pelita Informatika, 16., pp.428-432.

[14] Guntur, M., Santony, J., \& Yuhandri., 2018. Prediksi Harga Emas dengan Menggunakan Metode Naïve Bayes dalam Investasi untuk Meminimalisasi Resiko. Jurnal RESTI (Rekayasa Sistem Dan Teknologi Informasi), 2(1), pp.354-360. http://doi.org/https://doi.org/10.29207/resti.v2i1.276 